AGRITECH, Vol. 37, No. 3, Agustus 2017, Hal. 246-255 DOI: http://doi.org/10.22146/agritech.10846 ISSN 0216-0455 (Print), ISSN 2527-3825 (Online) Tersedia online di https://jurnal.ugm.ac.id/agritech/

\title{
Aktivitas Antioksidan dan Angiotensin-I Converting Enzyme Inhibitor oleh Yogurt dengan Ekstrak Daun Ficus glomerata Roxb
}

\author{
Antioxidant activity and Angiotensin-I Converting Enzyme Inhibitor of Yogurt with Ficus glomerata Roxb Leaf Extract \\ Baiq Rani Dewi Wulandani ${ }^{1 *}$, Endang Sutriswati Rahayu², Yustinus Marsono², Tyas Utami² \\ ${ }^{1}$ Program Studi Ilmu Peternakan, Fakultas Peternakan, Universitas Mataram, \\ J1. Majapahit No. 62, Mataram, Nusa Tenggara Barat 83521, Indonesia \\ ${ }^{2}$ Departemen Teknologi Pangan dan Hasil Pertanian, Fakultas Teknologi Pertanian, Universitas Gadjah Mada, \\ J1. Flora No.1, Bulaksumur, Yogyakarta 55281, Indonesia \\ Email: rani.wulandani@gmail.com
}

Submisi: 11 Mei 2016; Penerimaan: 26 Januari 2017

\begin{abstract}
ABSTRAK
Ficus glomerata Roxb. telah diketahui memiliki senyawa flavonoid. Senyawa flavonoid yang terdapat didalam tanaman diketahui memiliki kemampuan sebagai antioksidan dan mampu sebagai Angiotensin Converting Enzyme I- inhibitor. Penelitian ini diawali dengan melakukan ekstraksi dengan menggunakan air pada daun Ficus glomerata Roxb untuk mendapatkan profil senyawa phenolik pada ekstrak daun Ficus glomerata Roxb [gallic acid, flavonol (quercetin dan rutin), flavanol (catechin), dan flavanone]. Tahap berikutnya adalah inokulasi dan perbanyakan starter yogurt untuk selanjutnya melakukan proses pembuatan yogurt dengan penambahan ekstrak daun Ficus glomerata Roxb. Pengujian aktivitas antioksidan, pengujian terhadap nilai o-phthalaldehyde (OPA) dan pengujan terhadap angiotensin converting enzyme I- inhibitor dilakukan terhadap yogurt dengan ekstrak daun Ficus glomerata Roxb selama proses penyimpanan. Tujuan dari penelitian ini adalah untuk mempelajari kemampuan aktivitas antioksidan dan Angiotensin Converting Enzyme I- inhibitor pada yogurt dengan penambahan ekstrak daun Ficus glomerata Roxb selama penyimpanan (1, 7, 14, 21, dan 28 hari) pada suhu $4{ }^{\circ} \mathrm{C}$. Hasil yang diperoleh menunjukkan bahwa aktivitas antioksidan, nilai o-phthalaldehyde (OPA) dan Angiotensin Converting Enzyme I- inhibitor pada yogurt dengan ekstrak daun Ficus glomerata Roxb selama proses penyimpanan di dalam refrigerator $\left(4^{\circ} \mathrm{C}\right)$ adalah lebih tinggi dan menunjukkan perbedaan yang nyata $(p<0,05)$ dibandingkan dengan plain yogurt yang mencapai optimalnya pada hari ke-7 penyimpanan.
\end{abstract}

Kata kunci: Angiotensin converting enzyme; Ficus glomerata Roxb; yogurt

\begin{abstract}
Ficus glomerata Roxb has been known to have flavonoids. Flavonoids in plant are known for their antioxidant activity and ability to the Angiotensin Converting Enzyme I- inhibitor. This research started with extraction using water on the leaves of Ficus glomerata Roxb to obtained profile of phenolic compounds in the leaves of Ficus glomerata Roxb [gallic acid, flavonol (quercetin dan rutin), flavanol (catechin), dan flavanone]. The next stage was to prepare of yogurt starter inoculation and propagation of starter yogurt and yogurt- making process with the addition of the leaf extract of Ficus glomerata Roxb during the storage process. The purpose of this research is to study the antioxidant activity ability and Angiotensin Converting Enzyme I- inhibitor of yogurt with Ficus glomerata leaf extract during storage times $\left(1,7,14,21\right.$, and 28 days) at $4{ }^{\circ} \mathrm{C}$. The results showed that the antioxidant activity, the value of ophthalaldehyde (OPA) and Angiotensin Converting Enzyme I- Inhibition on Ficus glomerata -yogurt during storage in the refrigerator $\left(4{ }^{\circ} \mathrm{C}\right)$ is higher and show differences significantly $(p<0,05)$ compared with plain yogurt that reaches optimal on day 7 of storage.
\end{abstract}

Keywords: Angiotensin converting enzyme; Ficus glomerata Roxb; yogurt 


\section{PENDAHULUAN}

Ficus glomerata Roxb merupakan spesies tanaman yang termasuk ke dalam family Moraceae yang popular diketahui sebagai Cluster fig tree, Indian fig tree, goolar (gular) fig, merupakan tanaman asli Australia, Malaysia, Asia Tenggara dan benua India. Menurut Plantamor (2012) Ficus glomerata Roxb merupakan salah satu tanaman yang kaya akan sumber fitokimia (termasuk senyawa fenolik) dan memiliki aktivitas antioksidan, termasuk yang terdapat di dalam tanaman Ficus glomerata Roxb. Total aktivitas antioksidan pada buah dan daun Ficus glomerata masingmasing adalah 74,31 dan 101,35 ( $\mu$ g ascorbic acid equivalent per mg berat kering) (Ahmed dan Tariq, 2012). Di samping itu, pada tanaman yang kaya senyawa phenolik diketahui juga memiliki kemampuan sebagai Angiotensin Converting Enzyme I-inhibitor (ACE I- inhibitor). Angiotensin Converting Enzyme adalah enzim yang berperan dalam regulasi tekanan darah dalam sistem Renin Angiotensin System (RAAS) yang berperan penting dalam mengatur tekanan darah yaitu dengan cara mengubah prekursor angiotensin I menjadi angiotensin II, yaitu peptida yang berperan dalam memicu mekanisme peningkatan tekanan darah, memicu pengeluaran aldosteron, dan pengeluaran ADH yang kesemuanya akan menyebabkan meningkatnya tekanan darah. Oleh karena itu penghambatan ACE merupakan cara yang menjanjikan untuk mengontrol aktivitas RAAS. Angiotensin Converting Enzyme akan menginaktivasi bradikinin, suatu vasodilator yang menyebabkan relaksasi darah setelah berkontraksi. Oleh karena itu penghambatan terhadap aktivitas ACE adalah target utama dalam pencegahan hipertensi.

Potensi Ficus glomerata Roxb yang diinklusikan kedalam yogurt sebagai sumber antioksidan dan sebagai penghasil Angiotensin Converting Enzyme I- inhibitor belum pernah diteliti. Kajian selanjutnya adalah mengetahui bagaimana stabilitas aktivitas antioksidan dan Angiotensin Converting Enzyme I-inhibitor selama 28 hari proses penyimpanan yogurt didalam refrigerator $\left(4^{\circ} \mathrm{C}\right)$ pada yogurt dengan ekstrak daun Ficus glomerata Roxb. Penyimpanan dilakukan selama 28 hari yaitu sebelum masa simpan maksimal yogurt pada suhu $4{ }^{\circ} \mathrm{C}$. Hal ini berdasarkan WFLO commodity Storage Manual (2008) bahwa masa simpan maksimal yaitu berkisar antara 35 hingga 45 hari pada suhu penyimpanan berkisar antara $2-4,4{ }^{\circ} \mathrm{C}$. Penelitian ini dilakukan bertujuan untuk mengetahui aktivitas antioksidan dan Angiotensin Converting Enzyme I-inhibitor selama proses penyimpanan yogurt di dalam refrigerator $\left(4{ }^{\circ} \mathrm{C}\right)$ dengan adanya penamnahan ekstrak ekstrak daun Ficus glomerata Roxb.

\section{METODE PENELITIAN}

\section{Bahan dan Alat}

Bahan utama penelitian adalah daun Ficus glomerata Roxb yang diperoleh pada desa Leneng, Praya, Lombok Tengah, Nusa Tenggara Barat. Starter bakteri yang digunakan dalam proses pembuatan yogurt adalah Lactobacillus bulgaricus (FNCC 0041) dan Streptococcus thermophilus (FNCC 0015) yang diperoleh dari koleksi FNCC Pusat Studi Pangan dan Gizi, Universitas Gadjah Mada. Bahan yang digunakan dalam uji profil senyawa flavonoid adalah reagent standar berupa asam galat, quercetin rutin, flavanone, dan katekin yang diperoleh dari SIGMA. Alat yang digunakan untuk pengujian profil senyawa flavonoid daun Ficus glomerata Roxb menggunakan kromatografi lapis tipis.

\section{Tahapan Penelitian}

\section{Persiapan ekstraksi daun Ficus glomerata Roxb}

Sebanyak 200 g buah dan daun Ficus glomerata Roxb segar dipotong menjadi bagian-bagian kecil dan kemudian dikeringkan dengan menggunakan oven pada suhu $60{ }^{\circ} \mathrm{C}$ selama $\pm 12 \mathrm{jam}$, kemudian menghaluskan potongan buah dan daun Ficus glomerata Roxb yang telah kering dengan blender dan hasil yang diperoleh siap untuk diekstraksi.

\section{Ekstraksi daun Ficus glomerata}

Sebanyak $50 \mathrm{~g}$ bubuk buah dan daun Ficus glomerata Roxb ditimbang dan masing-masing ditambahkan dengan 500 $\mathrm{mL}$ aquadest dalam erlenmeyer berukuran $1 \mathrm{~L}$ dan dilarutkan, kemudian masing-masing erlenmeyer dimasukkan ke dalam waterbath pada suhu $45^{\circ} \mathrm{C}$ selama \pm 12 jam. Supernatan yang diperoleh kemudian dikumpulkan dan dimasukkan ke dalam beberapa botol konikal plastik (masing-masing berukuran $30 \mathrm{~mL}$ ) untuk kemudian disimpan pada suhu $4{ }^{\circ} \mathrm{C}$ ) sampai pengujian dilakukan.

\section{Pengujian profil senyawa flavonoid daun Ficus glomerata Roxb}

Plate dipotong (untuk satu spot menggunakan plate dengan lebar sekitar $1 \mathrm{~cm}$ ). Membuat garis dasar (base line) dibagian bawah sekitar $0,5 \mathrm{~cm}$ dari ujung bawah plate dan garis akhir dibagian atas plat. Pengujian dilakukan untuk masing-masing perlakuan standar dengan cara mengambil 10 $\mu \mathrm{L}$ sampel ekstrak buah menggunakan mikropipet. Sampel ditempatkan di atas cawan porselin yang kemudian dilakukan evaporasi menggunakan penangas air dan dilarutkan dalam ethanol 50\% 0,2 $\mathrm{mL}$ dan dengan menggunakan pipet kapiler dilakukan spoting sampel $(40 \mu \mathrm{L})$ pada plat silica gel $\mathrm{F}_{254}$ (sebagai fase diam). Sertakan pembanding (standar), 
kemudian plate dimasukkan ke dalam chamber yang berisi fase gerak, yaitu: Etil asetat-metanol-asamformiat (3:1:1) untuk quercetin; butanol-asam asetat-air $(3: 1: 1)$ untuk rutin; Chloroform-Asam Asetat-Asam Formiat- Iso Propanol (162-2-8) untuk catechin; metanol-asam formiat (95:5) untuk gallic acid; Chloroform-etil asetat (90:10) untuk flavones dan flavonone, kemudian menutup chamber. Menunggu eluen mengelusi sampel sampai mencapai garis akhir sehingga terlihat adanya pemisahan (sekitar \pm 30 menit). Setelah mencapai garis akhir (sekitas $0,5 \mathrm{~cm}$ dari batas plate). Kemudian dilakukan pengangkatan plate menggunakan pinset dan ditunggu hingga kering. Densito dilakukan pada panjang gelombang $341 \mathrm{~nm}$ menggunakan TLC scanner.

\section{Persiapan starter kultur}

Membuka ampul masing- masing starter bakteri Streptococcus thermophilus dan Lactobacillus bulgaricus secara aseptis dengan memotong ampul, kemudian diteteskan kedalamnya 3-5 tetes larutan natrium klorida fisiologis steril/ broth dan suspensi yang dibentuk kemudian diinokulasi kedalam MRS broth $(50 \mathrm{~mL})$ dan diinkubasi pada suhu $37{ }^{\circ} \mathrm{C}$ selama 24 jam. Maing-masing 12.5 Streptococcus thermophilus dan Lactobacillus bulgaricus biakan dari MRS broth dimasukkan kedalam susu UHT (250 mL) dan diinkubasi pada $37{ }^{\circ} \mathrm{C}$ selama 24 jam.

\section{Proses pembuatan yogurt}

Plain yogurt (yogurt tanpa penambahan ekstrak daun Ficus glomerata Roxb) dan yogurt dengan ekstrak daun Ficus glomerata Roxb disiapkan pada hari yang sama. Hasil ekstraksi daun Ficus glomerata Roxb menggunakan air (100 mL) ditambahkan pada susu full cream cair yang telah dipasteurisasi sebelumnya $(820 \mathrm{~mL})$ dan susu skim $(30$ $\mathrm{mL}$ ), diikuti dengan penambahan starter kultur campuran Streptococcus thermophilus dan Lactobacillus bulgaricus (masing-masing $50 \mathrm{~mL}$ ). Pada perlakuan plain yogurt dipersiapkan dengan cara yang sama dengan yogurt yang ditambah dengan ekstrak daun Ficus glomerata Roxb, namun $100 \mathrm{~mL}$ air destilasi digunakan sebagai pengganti ekstrak Ficus glomerata. Yogurt kemudian difermentasi di dalam water bath $\left(43^{\circ} \mathrm{C}\right)$ hingga $\mathrm{pH}$ mencapai 4,5 diikuti dengan penyimpanan di dalam refrigerator untuk penyimpanan selama 1, 7, 14, 21, dan 28 hari.

\section{Proses ekstraksi yogurt}

Plain yogurt dan yogurt dengan ekstrak daun Ficus glomerata (10 g) dihomogenisasi dengan menggunakan 2,5 $\mathrm{mL}$ air destilasi steril. $\mathrm{pH}$ yogurt diatur sebesar 4,0 dengan $\mathrm{HCl}(0,1 \mathrm{M})$. Yogurt kemudian dipanaskan dalam water bath $\left(45^{\circ} \mathrm{C}\right)$ selama 10 menit, diikuti dengan sentrifugasi
(5000 g, 10 menit, $\left.4{ }^{\circ} \mathrm{C}\right), \mathrm{NaOH}(0,1 \mathrm{M})$ ditambahkan untuk menyesuaikan $\mathrm{pH}$ supernatan yaitu $\mathrm{pH}$ 7,0. Supernatant di sentrifugasi kembali pada (5000 g, 10 menit, $4{ }^{\circ} \mathrm{C}$ ). Supernatan diambil dan disimpan pada $-20{ }^{\circ} \mathrm{C}$ pada freezer sampai digunakan untuk analisis.

\section{Penentuan pH dan total titratable acid (TTA)}

Yogurt awalnya dihomogenisasi dengan air (rasio 1:9) sebelum pengukuran $\mathrm{pH}$. Pengukuran $\mathrm{pH}$ dilakukan dengan $\mathrm{pH}$ meter. Total titratable acid (TTA) selama proses fermentasi yogurt ditentukan dengan titrasi menggunakan $0,1 \mathrm{~N} \mathrm{NaOH}$. Sebanyak $1 \mathrm{~mL}$ yogurt dimasukkan ke dalam tabung erlenmeyer yang telah terisi $9 \mathrm{~mL}$ air destilasi. Sebanyak 3-5 tetes $0,1 \%$ phenolphthalein ditambahkan sebagai $\mathrm{pH}$ indikator. $\mathrm{NaOH}(0,1 \mathrm{~N})$ dititrasi ke dalam larutan dan larutan dicampur seluruhnya. Proses diulang hingga terjadi perubahan indikator menjadi warna merah jambu yang konstan. Setelah $1 \mathrm{~mL} \mathrm{0,1} \mathrm{NaOH}$ dinetralisasi dengan 0,009 g asam, jumlah asam yang dihasilkan selama fermentasi dapat ditentukan, yaitu dengan Persamaan (1):

Persentase asam laktat $=$

faktor dilusi (10)* $\mathrm{V} \mathrm{NaOH}^{*} 0,1 \mathrm{~N}^{*} 0,009 * 100 \%$

Dimana $\mathrm{V}$ adalah volume $\mathrm{NaOH}$ yang dibutuhkan untuk menetralkan asam.

\section{Pengujian total fenolik yogurt}

Total fenolik yogurt dilakukan dengan menggunakan metode yang dilakukan oleh Shetty dkk. (1995). Satu milliliter ekstrak yogurt dipindahkan kedalam tabung uji yang memiliki penutup dan dicampurkan dengan $1 \mathrm{~mL}$ ethanol $95 \%$ dan 5 $\mathrm{mL}$ air dan ditambahkan serta dicampurkan 0,5 mL 50\% (v/v) reagent Folin- Ciocalteu (1:1 dengan air destilasi) selama 5 menit pada suhu ruang. Satu $\mathrm{mL} 5 \% \mathrm{Na}_{2} \mathrm{CO}_{3}$ ditambahkan dan diinkubasi selama 60 menit pada suhu ruang. Absorbansi dibaca pada $725 \mathrm{~nm}$. Nilai absorbansi dikonversi untuk TPC dan ditunjukkan dalam microgram equivalent asam galat per milliliter sampel. Kurva standar ditentukan dengan menggunakan beberapa konsentrasi asam galat $(5-60 \mu \mathrm{g} / \mathrm{mL}$ ethanol 95\%).

Penentuan aktivitas antioksidan menggunakan 1,1 Diphenyl - 2 Picrylhydrazyl (DPPH) radical inhibition assay

Ekstrak yogurt $(250 \mu \mathrm{L})$ ditambahkan ke dalam $3 \mathrm{~mL}$ $60 \mathrm{mmol} / \mathrm{L}$ DPPH (Sigma-Aldrich, Germany)/L ethanol. Pengurangan absorbansi dimonitor pada $517 \mathrm{~nm}$ hingga pembacaan konstan diperoleh. Hasil pembacaan konstan untuk ekstrak yogurt dan kontrol (yang mengandung $250 \mu \mathrm{L}$ air sebagai pengganti ekstrak yogurt) digu 
menghitung \% penghambatan oksidasi DPPH (Apostolidis dkk., 2007) (Persamaan 2).

$$
\text { Penghambatan DPPH }(\%)=\frac{\text { A.kontrol 517-A.ekstrak 517 }}{\text { A.kontrol } 517} \times 100
$$

\section{O-Phthalaldehyde (OPA) assay}

Hasil proteolisis pada yogurt ekstrak dihitung menggunakan o- phthalaldehyde yang bereaksi dengan amina primer (grup fungsional peptida) dengan adanya mercaptoethanol (Church dkk., 1983). Persiapan OPA reagent: larutan OPA dibuat dengan mengkombinasikan reagen : 25 $\mathrm{mL} 100 \mathrm{mM}$ sodium tetraborate, 2,5 $\mathrm{ml} \mathrm{20 \%}$ (wt/wt) sodium dodecyl -sulfate (SDS) dan 1,1 mL OPA (40 mg OPA yang dilarutkan dalam $1 \mathrm{~mL}$ methanol $+100 \mu 1 \beta$-mercaptoethanol) (Sigma-Aldrich, Germani) yang dicampurkan ke dalam 21,4 mL d $\mathrm{H}_{2} \mathrm{O}$ (Goodno dkk., 1981). Reagen OPA sensitif terhadap cahaya dan harus dilindungi dari sumber cahaya selama persiapan dan pengujian. Reagen harus dipersiapkan dalam keadaan segar dan digunakan dalam waktu 2 jam setelah persiapan. Aliquot ekstrak yogurt (sekitar $50 \mu \mathrm{l}$ yang mengandung 5-100 $\mu \mathrm{g}$ protein) ditambahkan secara langsung pada 1,0 mL reagent OPA dalam cuvette $1,5 \mathrm{~mL}$. Larutan dicampur secara cepat dengan inverse/pembalikan dan diinkubasi selama 2 menit pada suhu ruang. Absorbansi dibaca pada $340 \mathrm{~nm}$ (Spectronic 10 UV (190-1100 nm)). Konsentrasi peptida diestimasi terhadap kurva standar trypton (Difco laboratories, Spark, MD USA) standards (0,25-150 $\mathrm{mg} / \mathrm{mL})$.

\section{Kurva standar trypton}

Kurva standar konsentrasi peptida dilakukan dengan menggunakan trypton. Beberapa konsentrasi trypton standar $(0,2 ; 0,5 ; 0,75 ; 1,00 ; 1,25 ; 1,50 \mathrm{mg} / \mathrm{mL})$ dipersiapkan dari larutan stok. Trypton standar dipersiapkan dan diperlakukan sama untuk masing-masing pengujian OPA sehingga dihasilkan linier regresi antara abs (340 nm) dan trypton.

Aktivitas penghambatan angiotensin converting enzyme (ACE) menggunakan metode Cheung dan Chusman (1971) dengan modifikasi dalam Byun dan Kim, 2002

Sebanyak 50 L ekstrak yogurt Ficus glomerata Roxb dan $50 \mu \mathrm{L}$ larutan ACE (25 mU/mL) dilakukan pra-inkubasi pada $32{ }^{\circ} \mathrm{C}$ selama 10 menit. Campuran diinkubasi dengan $50 \mu \mathrm{L}$ substrat (Hip-His-Leu $8 \mathrm{mM}$ dalam bufer HEPES 50 $\mathrm{mM}$ yang mengandung $\mathrm{NaCl} 300 \mathrm{mM}$ pada $\mathrm{pH}$ 8,3) selama 30 menit pada suhu yang sama. Reaksi diakhiri dengan penambahan $\mathrm{HCl} 1 \mathrm{M}(200 \mu \mathrm{L})$. Larutan diekstraksi dengan penambahan $1,5 \mathrm{~mL}$ etil asetat, dan disentrifugasi $(4000 \times \mathrm{g})$ selama 15 menit. Satu mL supernatan dipindahkan ke tabung reaksi yang lain dan diuapkan pada suhu kamar selama 2 jam dalam vakum atau pengering oven. Setelah kering, dilarutkan dalam $3 \mathrm{~mL}$ air distilasi dan absorbans ditentukan pada panjang gelombang $228 \mathrm{~nm}$ menggunakan spektrofotomer UV-Vis. Aktifitas ACE Inhibitor dihitung sebagai prosentase penghambatan terhadap aktifitas $A C E$ dengan Persamaan 3:

Persentase penghambatan $=(A-B)(A-C) \times 100 \%$

$\mathrm{A}=$ Absorbansi enzim ACE + Substrat

$\mathrm{B}=$ Absorbansi sampel + enzim $\mathrm{ACE}+$ substrat

$\mathrm{C}=$ Absorbansi substrat + sampel

\section{HASIL DAN PEMBAHASAN}

\section{Efek Pemberian Ekstrak Daun Ficus glomerata Roxb terhadap pH dan TTA yogurt}

Hasil yang diperoleh terhadap $\mathrm{pH}$ pada saat proses fermentasi menunjukkan bahwa baik plain yogurt dan yogurt yang ditambahkan ekstrak daun Ficus glomerata Roxb menunjukkan nilai $\mathrm{pH}$ awal (jam ke-0) yang sama, masingmasing yaitu 5,85 $\pm 0,03$ (pada plain yogurt) dan 5,81 $\pm 0,03$ (pada yogurt dengan ekstrak daun Ficus glomerata Roxb) dan nilai $\mathrm{pH}$ pada akhir fermentasi masing- masing adalah $4,58 \pm$ 0,01 (plain yogurt) dan 5,54 $\pm 0,03$ (yogurt dengan daun Ficus glomerata) yang dicapai pada fermentasi. Berdasarkan hasil analisis ragam (ANOVA) menunjukkan bahwa pada masingmasing perlakuan yogurt tidak menunjukkan perbedaan yang nyata $(p \geq 0,05)$.

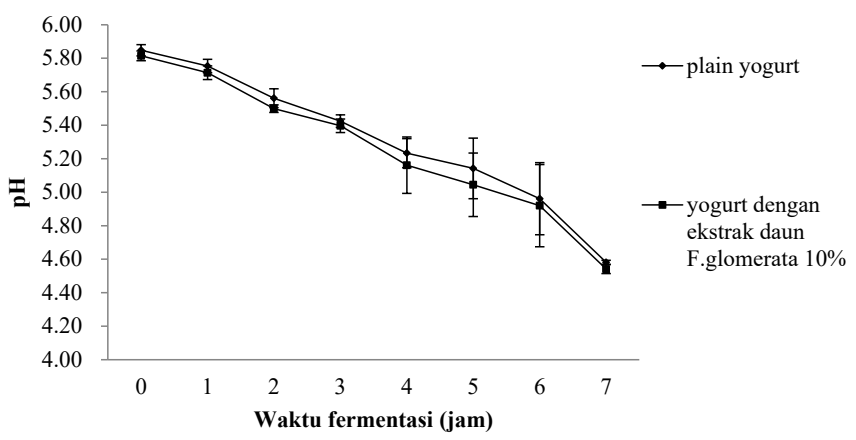

Gambar 1. Perubahan $\mathrm{pH}$ selama proses fermentasi yogurt untuk plain dan

Hasil ini sejalan dengan nilai total titratable acid (TTA) pada jam ke-0 fermentasi adalah 0,25 $\pm 0,03$ (plain yogurt) dan 0,29 \pm 0,04 (yogurt dengan daun Ficus glomerata) dan nilai TTA pada jam ke-7 fermentasi menunjukkan masingmasing adalah $0,70 \pm 0,05$ (plain yogurt atau yogurt tanpa penambahan ekstrak daun Ficus glomerata Roxb) dan 0,77 $\pm 0,04$ (yogurt dengan ekstrak daun Ficus glomerata Roxb) namun tidak menunjukkan perbedaan yang nyata $(p \geq 0,05)$. 


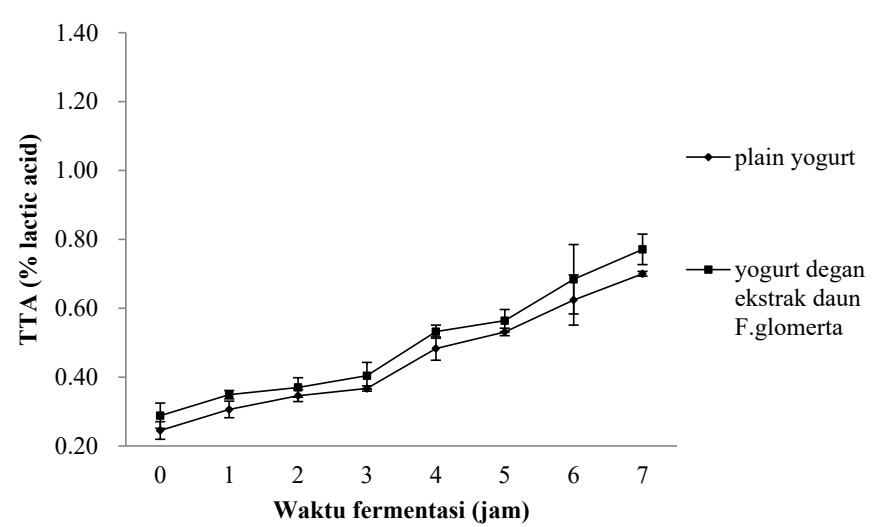

Gambar 2. Perubahan TTA selama proses fermentasi yogurt untuk plain dan yogurt dengan ekstrak daun Ficus glomerata Roxb. Setiap perlakuan diulang sebanyak tiga kali dengan nilai adalah mean $\pm \mathrm{SD}$

Pada hari ke-1 penyimpanan di dalam refrigerator $\mathrm{pH}$ yang dicapai oleh masing-masing perlakuan adalah 4,49 \pm 0,00 (plain yogurt) dan 4,43 $\pm 0,00$ (yogurt dengan ekstrak daun Ficus glomerata Roxb) ( $p \leq 0,05)$ dengan nilai TTA masing-masing adalah $0,73 \pm 0,01$ (plain yogurt) dan $0,82 \pm$ 0,00 (yogurt dengan ekstrak daun Ficus glomerata Roxb) ( $p$ $\leq 0,05)$.

Penurunan nilaipH terus berlangsung hingga hari terakhir (hari ke-28) penyimpanan untuk masing-masing perlakuan. $\mathrm{pH}$ pada hari terakhir penyimpanan adalah 4,28 $\pm 0,01$ (plain yogurt) dan 4,14 $\pm 0,02$ (yogurt dengan ekstrak daun Ficus glomerata Roxb) ( $p \leq 0,05)$ dengan nilai TTA adalah 1,06 $\pm 0,01$ (pada plain yogurt) dan 1,26 $\pm 0,01$ (yogurt dengan ekstrak daun Ficus glomerata Roxb) ( $p \leq 0,05)$. Menurut Vedamuthu (1982) bahwa perpanjangan waktu penyimpanan yogurt menjadi 28 hari yang menyebabkan penurunan $\mathrm{pH}$ $(4,2-4,4)$ kemungkinan terjadi akibat akumulasi asam asetat,

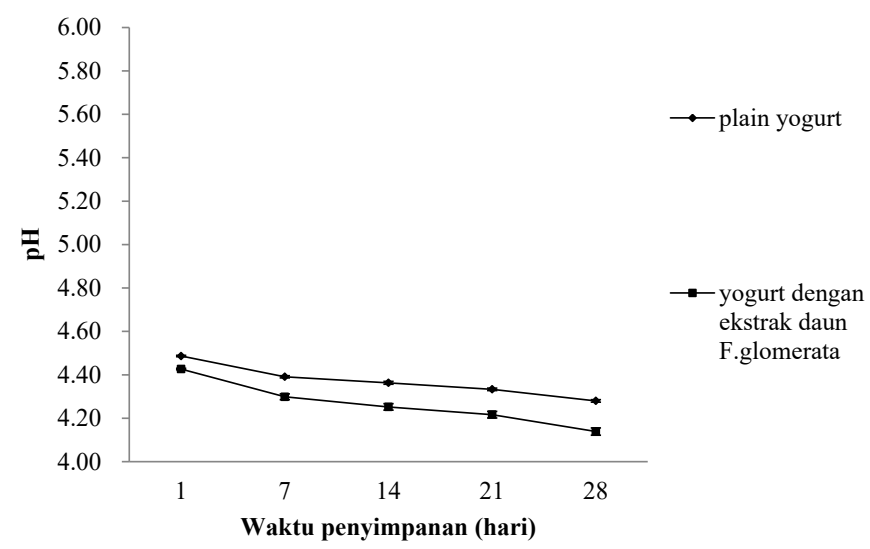

Gambar 3. Perubahan $\mathrm{pH}$ selama proses penyimpanan yogurt (28 hari, $4{ }^{\circ} \mathrm{C}$ ) untuk plain dan yogurt dengan ekstrak daun Ficus glomerata Roxb. Setiap perlakuan diulang sebanyak tiga kali dengan nilai adalah mean $\pm \mathrm{SD}$

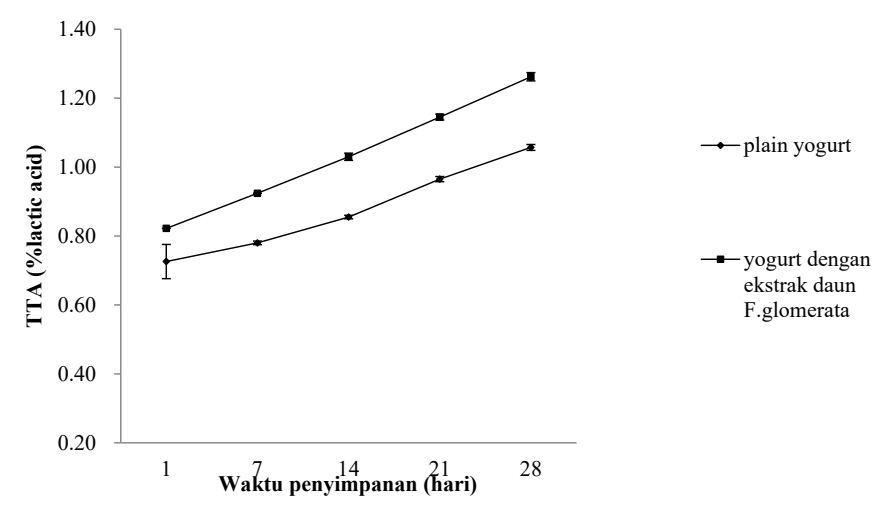

Gambar 4. Perubahan TTA selama proses penyimpanan yogurt (28 hari, $4{ }^{\circ} \mathrm{C}$ ) untuk plain dan yogurt dengan ekstrak daun Ficus glomerata Roxb. Setiap perlakuan diulang sebanyak tiga kali dengan nilai adalah mean $\pm \mathrm{SD}$

asetaldehida, asam formiat, dan asam laktat. Asam organik selama fermentasi dan penyimpanan yang diproduksi di dalam yogurt (asam laktat, asam sitrat, asam formiat, asam asetat, dan asam butirat (Ostlie dkk., 2005) memiliki hubungan linier dengan akumulasi TTA (Billard dkk., 2007).

\section{Total Phenolic Content}

Hasil yang diperoleh terhadap nilai total phenolic content selama proses fermentasi menunjukkan adanya peningkatan secara gradual selama fermentasi baik pada plain yogurt (yogurt tanpa ekstrak daun Ficus glomerata Roxb). Nilai total phenolic content pada plain yogurt dicerminkan dengan senyawa phenolik yang terkait dengan pemecahan protein susu (Damin dkk., 2009).

Total phenolic content (TPC) pada plain yogurt dan yogurt dengan penambahan ekstrak daun Ficus glomerata Roxb masing-masing adalah 6,72 $\pm 0,21 \mu \mathrm{g}$ GAE/mL dan $19,93 \pm 0,30 \mu \mathrm{g}$ GAE/mL pada jam ke-0 fermentasi dan masing-masing mengalami peningkatan sebesar 49,40\% dan 22,63\% yaitu dengan nilai TPC masing-masing adalah $13,28 \pm 1,05 \mu \mathrm{g}$ GAE/mL dan 25,76 $\pm 0,84 \mu \mathrm{g}$ GAE/mL pada hari pertama penyimpanan yogurt di dalam refrigerator dan menunjukkan hasil yang berbeda nyata $(p<0,05)$. Kenaikan TPC terus menunjukkan peningkatan selama minggu pertama dan minggu ke-2 penyimpanan yogurt dan peningkatan terjadi secara konstan pada minggu ke-3 dan ke-4 penyimpanan. Pada minggu ke empat (hari ke-28) penyimpanan di dalam refrigerator masing-masing perlakuan mengalami peningkatan sebesar $24,37 \%$ dan $16,23 \%$ dibandingkan hari pertama penyimpanan dengan nilai TPC masingmasing adalah 17,56 $\pm 1,71$ (plain yogurt) dan 30,75 $\pm 0,94$ (yogurt dengan ekstrak daun Ficus glomerata) $(p<0,05)$. Nilai TPC pada plain yogurt dicerminkan dengan senyawa fenolik yang terkait dengan pemecahan protein susu (Damin 


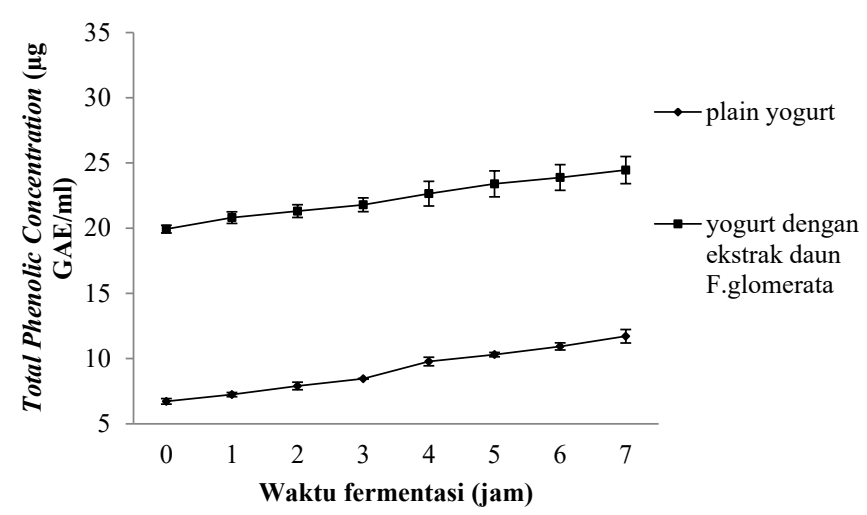

Gambar 5. Total phenolic concentration $(\mu \mathrm{gGEA} / \mathrm{mL})$ pada plain dan yogurt dengan ekstrak daun Ficus glomerata selama fermentasi. Setiap perlakuan diulang sebanyak tiga kali dengan nilai adalah mean $\pm \mathrm{SD}$. Total fenol diekspresikan sebagai $\mu \mathrm{g}$ asam galat equivalent ( $\mu \mathrm{g} \mathrm{GAE} / \mathrm{mL})$

dkk., 2009). Asam amino tyrosin misalnya, memiliki rantai samping fenolik (Shah, 2000) yang menimbulkan pembacaan adanya senyawa fenolik pada saat pembacaan absorbansi spektrofotometer.

Kemungkinan lainnya adalah bakteri asam laktat memanfaatkan asam fenolat seperti asam ferulat dan asam p-kaumarat selama proses fermentasi dan pasca asidifikasi yang menghasilkan asam fenolat lainnya seperti asam vanilat dan asam p-hidroksibenzoat sebelum struktur cincin aromatik diurai (Blum, 1998). Hal ini terjadi kemungkinan karena peran bakteri asam laktat terhadap senyawa fenolik yang terdapat baik di dalam buah maupun daun Ficus glomerata Roxb selama proses penyimpanan. Menurut Amirdivani dan Baba (2015) bahwa fermentasi yogurt mempengaruhi komponen bioaktif yang terdapat di dalam herbal. Maka dapat diasumsikan bahwa peningkatan nilai TPC berkonstribusi terhadap pemecahan lebih lanjut senyawa-senyawa fenolik

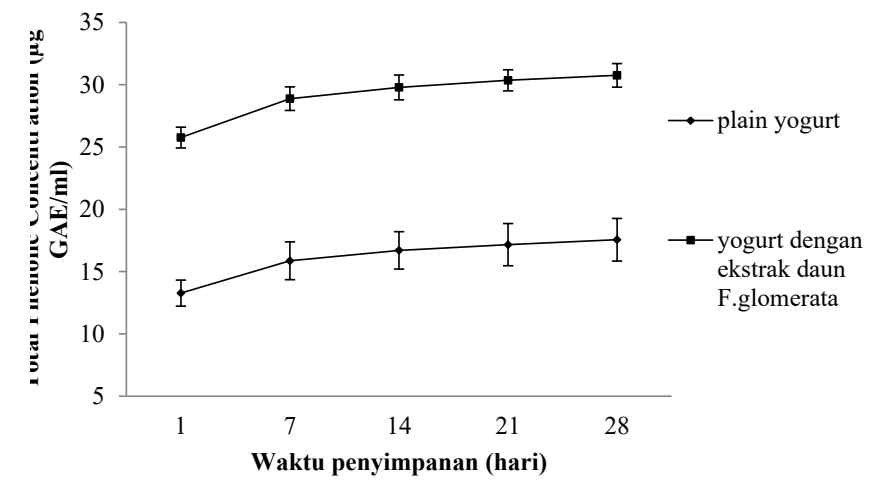

Gambar 6. Total phenolic concentration $(\mu \mathrm{gGEA} / \mathrm{mL})$ pada plain dan yogurt dengan ekstrak daun Ficus glomerata selama penyimpanan (4 ${ }^{\circ} \mathrm{C}$ ). Setiap perlakuan diulang sebanyak tiga kali dengan nilai adalah mean \pm SD. Total fenol diekspresikan sebagai $\mu \mathrm{g}$ asam galat equivalent ( $\mu \mathrm{g} \mathrm{GAE} / \mathrm{mL})$ selama fermentasi sebagai hasil dari aktivitas metabolik mikrobia. Selain itu, ikatan fenolik kemungkinan dilepaskan oleh aktivitas enzimatis mikrobia. Peningkatan dan penurunan terhadap total phenolic content di dalam yogurt dikarenakan peran bakteri asam laktat selama proses penyimpanan di dalam refrigerator yang mampu memecah lebih lanjut polimer senyawa fenolik. Polifenol diketahui memiliki afinitas yang kuat untuk mengikat protein yang mengarahkan pada pembentukan kompleks protein-polifenol (Dalling, 1986; Papadopoulou dan Frazier, 2004).

\section{Aktivitas Antioksidan}

Hasil yang diperoleh menunjukkan bahwa selama proses fermentasi maupun selama periode penyimpanan di dalam refrigerator (28 hari) diperoleh hasil bahwa yogurt dengan ekstrak daun Ficus glomerata Roxb memiliki aktivitas antioksidan yang lebih tinggi dibandingkan dengan plain yogurt. Aktivitas antioksidan pada jam ke-0 fermentasi pada masing-masing perlakuan plain yogurt dan yogurt dengan ekstrak daun Ficus glomerata adalah 18,07 \pm 1,84\% dan $24,56 \pm 0,62 \%$ dan mengalami peningkatan masingmasing sebesar $34,77 \%$ dan $32,88 \%$ dengan nilai aktivitas antioksidan adalah $27,70 \pm 1,84 \%$ (plain yogurt) dan 36,59 $\pm 1,29 \%$ (yogurt dengan ekstrak daun Ficus glomerata) pada hari ke-1 penyimpanan.

Aktivitas antioksidan mencapai maksimal pada hari ke-7 penyimpanan, yaitu 32,93 $\pm 2,48 \%$ (plain yogurt) dan 46,34 \pm 1,54\% (yogurt dengan ekstrak daun Ficus glomerata) dan mengalami penurunan sejak hari ke-14 hingga hari ke28 penyimpanan. Pada perlakuan plain yogurt mengalami penurunan sebesar $60,04 \%$, yaitu $13,16 \pm 0,25 \%$ dan pada perlakuan yogurt dengan ekstrak daun Ficus glomerata Roxb mengalami penurunan sebesar $52,09 \%$, yaitu $22,20 \pm 1,45 \%$.

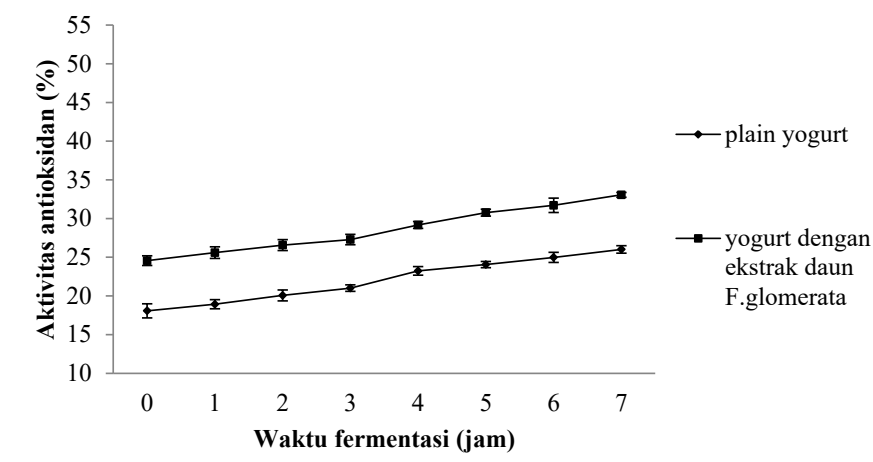

Gambar 7. Kapasitas antioksidan (\% penghambatan oksidasi DPPH) oleh plain dan yogurt dengan ekstrak daun Ficus glomerata selama fermentasi. Setiap perlakuan diulang sebanyak 3 kali dengan nilai mean $\pm \mathrm{SD}$ 


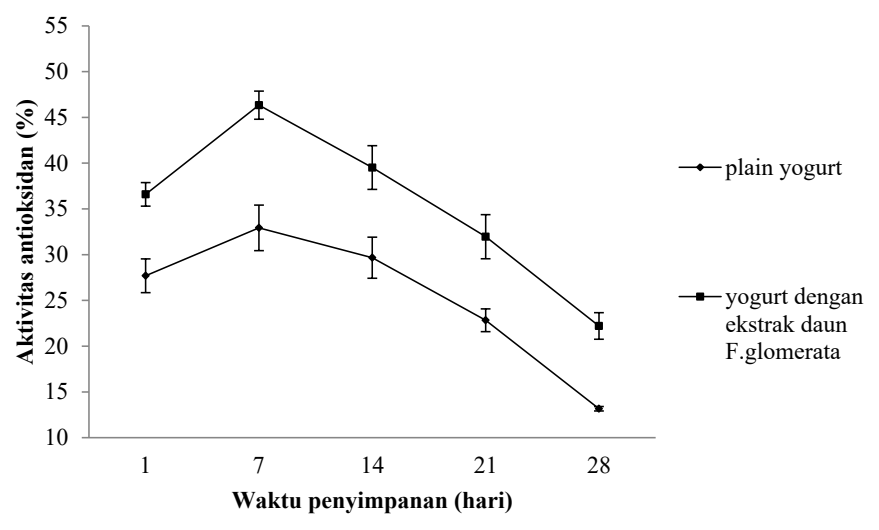

Gambar 8. Kapasitas antioksidan (\% penghambatan oksidasi DPPH) oleh plain dan yogurt dengan ekstrak daun Ficus glomerata selama 28 hari penyimpanan pada refrigerator $\left(4^{\circ} \mathrm{C}\right)$. Setiap perlakuan diulang sebanyak 3 kali dengan nilai mean $\pm \mathrm{SD}$

Menurut Thompson dkk. (2007) bahwa aktivitas antioksidan yang lebih tinggi pada Ficus glomerata-yogurt kemungkinan besar merupakan konstribusi masing-masing senyawa fitokimia dan sebagai hasil dari aktivitas metabolik mikrobia (bakteri asam laktat).

Tingginya penghambatan DPPH pada hari ke-7 penyimpanan didalam refrigerator dapat dikaitkan dengan aktivitas bakteria yogurt yang aktif secara metabolik bahkan pada suhu rendah. Pertumbuhan bakteria yang terus terjadi selama penyimpanan yogurt didalam refrigerator kemungkinan telah mengubah sebagian dari senyawa fenolik sehingga dapat merubah aktivitas antioksidan (Blum, 1998). Adanya bakteri asam laktat dalam fermentasi berkonstribusi terhadap konversi phenolik sederhana dan depolimerisasi senyawa phenolik dengan berat molekul tinggi (Othman dkk., 2009).

\section{Evaluasi Proteolisis dengan Uji o-phthalaldhyde (OPA)}

Hasil pengujian OPA menunjukkan bahwa nilai OPA pada awal fermentasi adalah 9,39 $\pm 0,41 \mathrm{mg} / \mathrm{g}$ dan 17,34 $\pm 0,83 \mathrm{mg} / \mathrm{g}$ masing masing untuk plain yogurt dan yogurt dengan ekstrak daun Ficus glomerata Roxb dan menunjukkan perbedaan yang nyata $(p \geq 0,05)$. Nilai OPA terus mengalami peningkatan selama proses fermentasi yaitu $24,70 \%$ untuk plain yogurt dan $15,62 \%$ pada yogurt dengan ekstrak daun Ficus glomerata Roxb sehingga nilai OPA pada akhir fermentasi adalah $12,47 \pm 0,60 \mathrm{mg} / \mathrm{g}$ pada plain yogurt dan $20,55 \pm 1,34 \mathrm{mg} / \mathrm{g}$ yang menunjukkan perbedaan yang nyata $(p<0,05)$. Kenaikan optimal untuk nilai OPA baik untuk plain yogurt dan yogurt dengan ekstrak daun Ficus glomerata adalah pada hari ke-7 penyimpanan.

Nilai OPA untuk plain yogurt pada hari ke-1 penyimpanan adalah $17,17 \pm 1,04 \mathrm{mg} / \mathrm{g}$ pada plain yogurt (yogurt tanpa penambahan ekstrak daun Ficus glomerata Roxb) dan 25,13 $\pm 1,91 \mathrm{mg} / \mathrm{g}$ pada yogurt dengan ekstrak

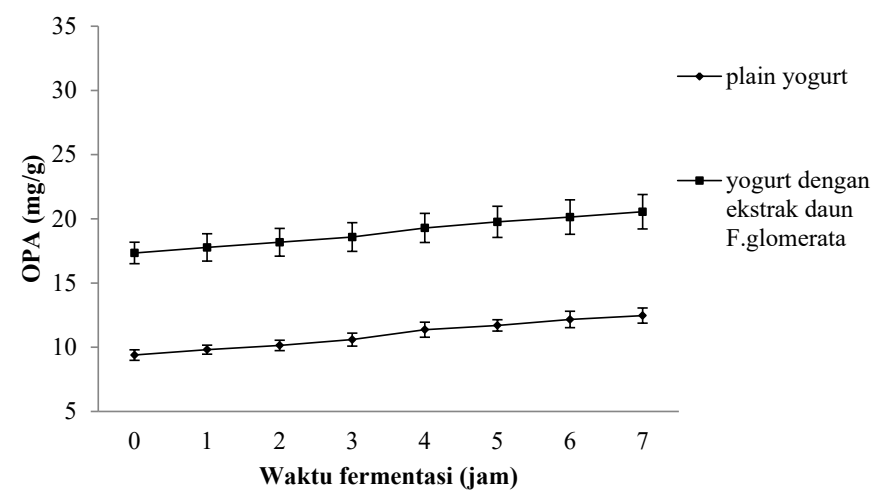

Gambar 9. Perubahan nilai OPA pada plain dan yogurt dengan ekstrak daun Ficus glomerata selama proses fermentasi. Setiap perlakuan diulang sebanyak 3 kali dengan nilai mean $\pm \mathrm{SD}$

daun Ficus glomerata Roxb dan pada hari ke-7 penyimpanan didalam refrigerator mengalami peningkatan sebesar 17,33\% pada plain yogurt yaitu $20,77 \pm 1,43 \mathrm{mg} / \mathrm{g}$ dan $20,70 \%$ pada yogurt dengan ekstrak daun Ficus glomerata yaitu 31,67 $\pm 2,39 \mathrm{mg} / \mathrm{g}$ dan menunjukkan perbedaan yang nyata $(p<$ $0,05)$. Menurut Papadimitriou dkk. (2007) diketahui bahwa $L$. acidophilus dan $S$. thermophilus adalah aktif secara metabolis bahkan pada $4{ }^{\circ} \mathrm{C}$ dan dengan demikian tingkat proteolisis oleh kedua bakteri ini kemungkinan mampu ditingkatkan dengan adanya ekstrak buah Ficus glomerata. Hal ini dapat mengakibatkan perubahan pemecahan protein yang menghasilkan peptida bioaktif yang lebih tinggi (Shahidi dan Zhong, 2008).

Nilai OPA meunjukkan penurunan setelah hari ke-7 penyimpanan di dalam refrigerator, baik untuk plain

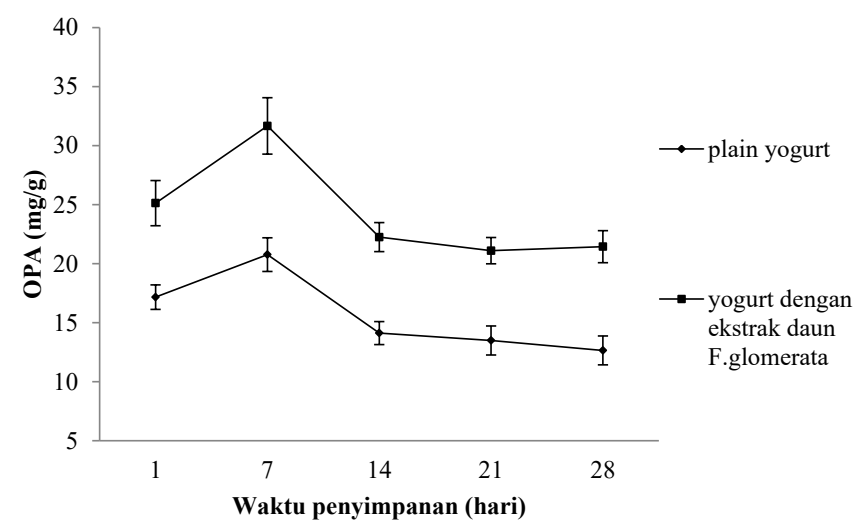

Gambar 10. Perubahan nilai OPA pada plain dan yogurt dengan ekstrak daun Ficus glomerata selama penyimpanan $\left(4{ }^{\circ} \mathrm{C}\right)$ untuk 28 hari. Setiap perlakuan diulang sebanyak 3 kali dengan nilai mean $\pm \mathrm{SD}$ 
yogurt maupun Ficus glomerata yogurt hingga hari ke-28 penyimpanan $\left(4^{\circ} \mathrm{C}\right)$. Pada hari ke-28 penyimpanan terjadi penurunan sebesar $39,09 \%$ pada plain yogurt, yaitu $12,65 \pm$ $1,23 \mathrm{mg} / \mathrm{g}$ pada plain yogurt dan $32,30 \%$ pada yogurt dengan ekstrak daun Ficus glomerata yang menunjukkan perbedaan yang nyata $(p<0,05)$. Meskipun penurunan nilai OPA menunjukkan penurunan gugus $\alpha$-amino yang bereaksi dengan mercaptoethanol yang menyebabkan penurunan serapan pada $340 \mathrm{~nm}$, hal ini tidak selalu mengimplikasikan penggunaan yang signifikan terhadap asam amino oleh bakteri yogurt. Degradasi asam amino akan menghasilkan rangka karbon yang digunakan sebagai nutrisi oleh LAB (Meisel dkk., 1997) dan lebih mungkin terjadi selama fermentasi pada suhu $41^{\circ} \mathrm{C}$ dibandingkan dengan penyimpanan pada susu $4{ }^{\circ} \mathrm{C}$.

\section{Penghambatan angiotensin-1 converting enzyme (ACE)}

Angiotensin-1 converting enzyme(ACE) assay dilakukan untuk mengevaluasi aktivitas penghambatan ACE oleh peptida bioaktif yang dihasilkan selama proses pembentukan yogurt dan selama penyimpanan didalam refrigerator (Gobbetti dkk., 2007). Hasil yang diperoleh untuk penghambatan ACE pada awal fermentasi adalah $20,82 \pm 0,45 \%$ pada plain yogurt dan $26,76 \pm 0,39 \%$ pada yogurt dengan ekstrak daun Ficus glomerata Roxb dan menunjukkan perbedaan yang nyata $(p \leq 0,05)$. Pada akhir proses fermentasi terjadi peningkatan sebesar $47,73 \%$, yaitu $39,83 \pm 0,78 \%$ pada plain yogurt dan 48,01 $\pm 0,66 \%$ pada yogurt dengan ekstrak daun Ficus glomerata Roxb dan menunjukkan perbedaan yang nyata $(p \leq 0,05)$. Nilai penghambatan ACE terus menunjukkan peningkatan hingga hari ke-7 penyimpanan $\left(4^{\circ} \mathrm{C}\right)$, yaitu 53,47 $\pm 1,07 \%$ pada plain yogurt dan $62,52 \pm 1,10 \%$ pada yogurt dengan ekstrak daun Ficus glomerata. Nilai penghambatan ACE terus mengalami penurunan secara gradual sejak hari

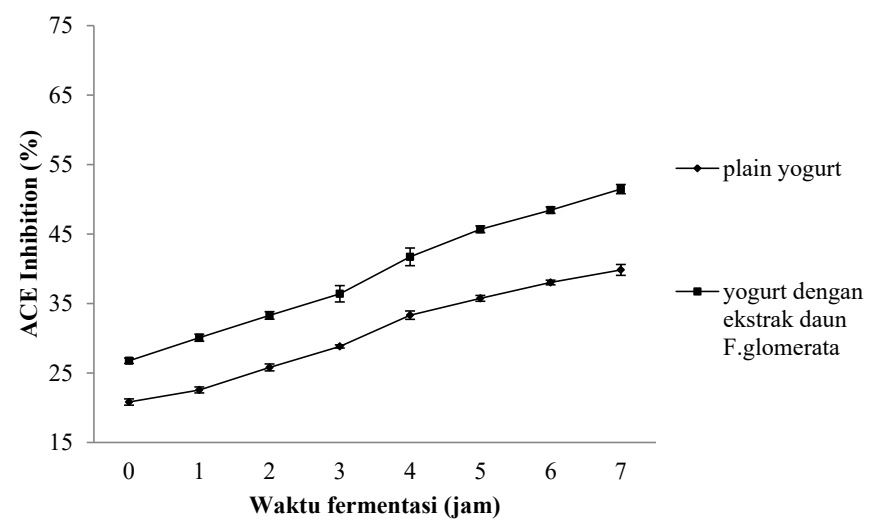

Gambar 11. Penghambatan ACE pada plain dan yogurt dengan ekstrak daun Ficus glomerata selama proses fermentasi. Setiap perlakuan diulang sebanyak 3 kali dengan nilai mean \pm SD

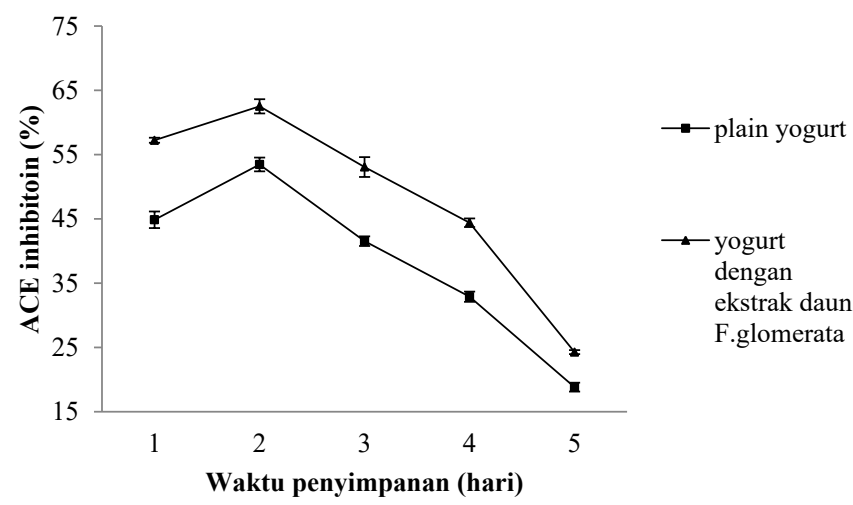

Gambar 12. Penghambatan ACE pada plain dan Ficus glomerata yogurt selama proses penyimpanan $\left(4^{\circ} \mathrm{C}\right)$ untuk 28 hari. Setiap perlakuan diulang sebanyak 3 kali dengan nilai mean \pm SD

ke-14 penyimpanan $\left(4^{\circ} \mathrm{C}\right)$ dan nilai terendah penghambatan diperoleh pada hari ke-28 penyimpanan. Penurunan nilai penghambatan ACE pada plain yogurt sebesar $64,82 \%$ pada plain yogurt, yaitu dengan nilai penghambatan ACE sebesar $18,82 \pm 0,69 \%$ dan penurunan nilai penghambatan ACE pada yogurt dengan ekstrak daun Ficus glomerata adalah 61,18\% dengan nilai penghambatan ACE sebesar 24,27 $\pm 0,31 \%$. Hasil ini seiring dengan peningkatan pembentukan peptida selama proses fermentasi dan mencapai nilai optimal pada hari ke-7 fermentasi.

Hal ini menunjukkan bahwa relatif lebih sedikit peptida spesifik yang dihasilkan selama fermentasi dan mengalami pembelahan lebih lanjut menjadi peptida yang lebih kecil dan lebih lebih banyak peptida bioaktif selama 7 hari penyimpanan didalam refrigerator. Proteolisis yang lebih lanjut pada protein selama waktu penyimpanan yang lebih lama (28 hari) menghasilkan peptida yang lebih kecil dan lebih sedikit peptida bioaktif. Penambahan ekstrak Ficus glomerata disaat proses pembuatan yogurt kemungkinan dapat merubah pola proteolisis yang kemudian membentuk dan melakukan deaktivasi protein dengan aktivitas anti ACE.

\section{KESIMPULAN}

Inklusi ekstrak daun Ficus glomerata mampu meningkatkan aktivitas antioksidan dan mampu meningkatkan pembentukan peptida dengan kemampuan anti ACE hingga pada hari ke-7 penyimpanan didalam refrigerator. Aktivitas proteolitis bakteria yogurt selama fermentasi dan penyimpanan $\left(4^{\circ} \mathrm{C}\right)$ adalah tertinggi dengan adanya ekstrak Ficus glomerata. Peningkatan penghambatan ACE secara in vitro adalah seiring dengan peningkatan pembentukan peptida selama proses fermentasi dan maksimal terjadi pada hari ke-7 penyimpanan didalam refrigerator. 


\section{DAFTAR PUSTAKA}

Ahmed, D. dan Tariq, S.A. (2012). In vitro studi of antimicrobial and antioxidant activities of methanolic extract of leaves fruit and bark of Ficus glomerata Roxb. International Journal of Medical and Aromatic Plants 2(1): 30-33.

Amirdivani, S. dan Baba, A.S. (2011). Changes in yogurt fermentation characteristics, and antioxidant potential and in vitro inhibition of angiotensin-1 converting enzyme upon the inclusion of peppermint, dill and basil. Jounal of LWT - Food Science and Technology 44: $1458-1464$.

Apostolidis, E., Kwon, Y.I.dan Shetty, K. (2007). Inhibitory potential of herb, fruit, and fungal-enriched cheese against key enzymes linked to type 2 diabetes and hypertension. Journal of Innovative Food Science and Emerging Technologies 8: 46-54.

Billard, I., Mekki, S., Ouadi, A. dan Gaillard, C. (2007). TTA solvation kinetics in theionic liquid BumimTf2N. Comptes Rendus Chimie 10: 1117-1121.

Blum, U. (1998). Effects of microbial utilization of phenolic acids and their phenolic acid breakdown products on allelpathic interactions. Journal of Chemical Ecology 24: $685-708$.

Byun, H.G. dan Kim, S.K. (2002). Structure and activity of angiotensin I converting enzyme inhibitory peptides derived from Alaskan pollack skin. Journal of Biochemistry and Molecular Biology 35(2): 239-43.

Church, F.C., Swaisgood, H.E., Porter, H.D. dan Catignani, G.L. (1983). Spectrophotometric assay using $o$-phthaldialdehyde for determination of proteolysis in milk and isolated milk proteins. Journal of Dairy Science 66(6): 1219-1227.

Dalling, M.J. (1986). Plant Proteolytic Enzymes. Volume. I dan II. CRC Press, Boca Raton, Florida.

Damin, M.R., Alcântara, M.R., Nunes, A.P. dan Oliveira, M.N. (2009). Effects of milk supplementation with skim milk powder, whey protein concentrate and sodium caseinate on acidification kinetics, rheological properties and structureof nonfat stirred yogurt. Journal of LWT-Food Science and Technology 17: 1744-1750.

Fitzgerald, R.J., Murray, B.A. dan Walsh, D.J. (2004). Hypotensive peptides from milk proteins. Journal of Nutrition 134: 980-988.
Gobbetti, M., Ferranti, P., Smacchi, E., Goffredi, F. dan Addeo, F. (2007). Production of angiotensin-i-convertingenzyme-inhibitory peptides in fermented milk started by Lactobacillus delbrueckii subs. Bulgaricus SS1 and Lactococcus lactis subsp. cremoris FT4. Journal ofApplied and Enviromental Microbiology 66(9): 3898 3904.

Goodno, C.C., Swaisgood, H.E. dan Catignani, G.L. (1981). A fluorimetric assay for available lysine in proteins. Analytical Biochemistry 115(1): 203-211.

Kwon, Y.I., Vattem, D.A. dan Shetty, K. (2006). Evaluation of clonal herbs of Lamiaceae species for management of diabetes and hypertension. Asia Pacific Journal of Clinical Nutrition 15: 107-118.

Meisel, H. (1997). Biochemical properties of Regulatory Peptides Derived from Milk Proteins. Hans Meisel Federal Dairy Research Centre, Institute for Chemistry and Physics. D-24121 Kiel. P.O.Box. 6069, Germany.

Ostlie, H.M., Treimo, J. dan Narvhus, J.A. (2005). Effect of temperature on growth and metabolism of probiotic bacteria in milk. International Dairy Journal 15: 989 997.

Othman, N.B., Roblain, D., Chammen, N., Thonart, P. dan Hamdi, M. (2009). Antioxidant phenolic compounds loss during the fermentation of Chétouiolives. Food Chemistry 116(3): 662-669.

Papadimitriou, C.G., Mastrojiannaki, A.V., Silva, A.V., Gomes, A.M., Malcata, F.X. dan Alichanidis, E. (2007). Identification of peptides in traditional and probiotic sheep milk yogurt with angiotensin I-converting enzyme (ACE)-inhibitoryactivity. Food Chemistry 105: $647-656$

Papadopoulou, A. dan Frazier, R.A. (2004). Characterization of protein-polyphenol interactions. Trends in Food Science and Technology 15: 186-190.

Shah, N.P. (2000). Effect of milk-derived bioactives: an overview. British Journal of Nutrition 84(1): 3-10.

Shahidi, F. dan Zhong, Y. (2008). Bioactive peptides. Journal of AOAC International 91: 914-931.

Shetty, K., Curtis, O.F., Levin, R.E., Witkowsky, R. dan Ang, W. (1995). Prevention of verification associated with in vitro shoot culture of oregano (Origanum vulgare) by Pseudomonas spp. Journal of Plant Physiology 147: 447-451. 
Thompson, J.L., Lopetcharat, K. dan Drake, M.A. (2007). Preferences for commercial strawberry drinkable yogurts among African American, Caucasian, and Hispanic consumers in the United States. Journal Dairy Science 90: 4974-4987.
Vedamuthu, E.R. (1982). Fermented milks. Dalam: Rose,A.H. (Ed.). Economic Microbiology: Fermented Foods, 199225. Academic Press, London. 